\title{
Bioremediation and Circular Biotechnology
}

\author{
Sunita Varjani ${ }^{1}$ Abhay Bajaj $^{2} \cdot$ Hemant J. Purohit $^{2}$ - V. C. Kalia ${ }^{3}$
}

Published online: 16 June 2021

(C) Association of Microbiologists of India 2021

In view of the growing interest in the field of Biotechnology in Bioremediation, the question being raised is to develop innovative technologies, which can be ecofriendly, economical and lead to improve the quality of human life. The need is to present the status of the diverse possibilities and the views and opinions of the experts to finally provide mankind with novel, innovative and long-lasting strategies, in the Special Issue of Indian Journal of Microbiology (INJM). INJM is an official Journal of Association of Microbiologists of India (AMI). In view of the vast diversity of experts as evident by their extremely valuable scientific publications in this area: Biotechnology in Bioremediation, we invited a few of them to contribute a review article or original research article to this Special Issue of INJM: "Bioremediation and Circular Biotechnology".

A major threat to environment is posed by synthetic organochlorine pesticides, primarily because of their highly

Hemant J. Purohit

hjp.neeri@gmail.com

$\triangle$ V. C. Kalia

vckaliaku@gmail.com

Sunita Varjani

drsvs18@gmail.com

Abhay Bajaj

abhaybajaj@gmail.com

1 Gujarat Pollution Control Board, Paryavaran Bhavan, $\mathrm{CHH}$ Road, Sector 10A, Gandhinagar 382 010, Gujarat, India

2 CSIR-National Environmental Engineering Research Institute (CSIR-NEERI), Nehru Marg, Nagpur 440020, India

3 Department of Chemical Engineering, Konkuk University, 1 Hwayang-Dong, Gwangjin-Gu, Seoul 05029, Republic of Korea persistent nature and bioaccumulation. Most of them impact the endocrine systems. Microbial processes for bioremediation of environmental pollutants are being pursued very vigorously. Fungi have the unique metabolic machinery for degrading these toxic and highly recalcitrant pollutants. A detailed biotransformation process and the biomaterial with high adsorbing capacity for removing pesticides and heavy metals have been highlighted in the article by Bokade et al., [1]. For comprehensive valorization of plant biomass waste, metabolic and functional potentials of microbes must be well understood. Whole genome sequencing of Streptomyces sp. genome has proven to be a fundamental tool for accurately mapping the lignocellulose metabolizing enzymes [2]. This finds support from the immobilization of degradtive enzymes on magnetic nanoparticles [3, 4]. Most industries depend heavily upon petroleum products leading to environmental pollution. The areas surrounding the petroleum refineries are the most adversely affected. An effective approach to mitigate these pollution levels can be the integration of bioremediation and resource recovery. Microbial ability to degrade petroleum refinery wastes with insights into resource reuse and recovery have been dealt in-depth in the article by Iman et al. [5].

Bioenergy production processes are primarily limited by the high feed cost. Microalgae has been attracting researchers as a cheap and clean source of raw material. Advantage can be taken of cultivating microalgae in wastewaters to achieve the target of proving feed and remediate wastewater using ecofriendly approaches. Algal-bacterial interaction has been realized to be the most efficient system, however, there are a few bottlenecks, which need to be overcome to promote a sustainable approach [6]. Dairy industry waste due to a high organic load are not recommended for discharging without 
treatment. Its potential as a source of value-added products such as biopolymers, biosurfactants, biofertilizers and single cell protein has been presented in the review of Adesra et al. [7]. The role of bioactive molecules in advancing biotechnology industries for human welfare have been now well recognized [8-10]. Food, agriculture, bioenergy, bioremediation and pharmaceuticals have integrated mammalian cells and algae as raw materials to reduce the cost of production. However, harvesting techniques for efficient recovery are under different stages of development [11].

Sunita Varjani (Guest Editor),

Abhay Bajaj (Guest Editor),

Hemant J. Purohit (Editor),

Vipin Chandra Kalia (Editor in Chief)

Acknowledgements We are extremely thankful to the authors and staff of the M/S Springer Nature especially Dr. Ms. Mamta Kapila, Ms. Suganya Maharajan, and Ms. Ramya Thulasingam for their kind cooperation and support in bringing out this special issue.

\section{References}

1. Bokade P, Purohit HJ, Bajaj A (2021) Myco-remediation of chlorinated pesticides: insights into fungal metabolic system. Indian J Microbiol. https://doi.org/10.1007/s12088-021-00940-8

2. Tikariha H, Pavagadhi S, Mayalagu S et al (2021) Hybrid genome assembly for predicting functional potential of a novel Streptomyces strain as plant biomass valorisation agent. Indian $\mathrm{J}$ Microbiol. https://doi.org/10.1007/s12088-021-00935-5

3. Otari SV, Patel SKS, Kalia VC, Lee JK (2020) One-step hydrothermal synthesis of magnetic rice straw for effective lipase immobilization and its application in esterification reaction.
Bioresour Technol 302:122887. https://doi.org/10.1016/j.bior tech.2020.122887

4. Patel SKS, Gupta RK, Kim SY, Kim IW, Kalia VC, Lee JK (2021) Rhus vernicifera laccase immobilization on magnetic nanoparticles to improve stability and its potential application in bisphenol a degradation. Indian J Microbiol 61:45-54. https://doi. org/10.1007/s12088-020-00912-4

5. Imam A, Kanaujia PK, Ray A et al (2021) Removal of petroleum contaminants through bioremediation with integrated concepts of resource recovery: A review. Indian J Microbiol. https://doi.org/ 10.1007/s12088-021-00928-4

6. Khoo KS, Chia WY, Chew KW et al (2021) Microalgal-bacterial consortia as future prospect in wastewater bioremediation, environmental management and bioenergy production. Indian $\mathrm{J}$ Microbiol. https://doi.org/10.1007/s12088-021-00924-8

7. Adesra A, Srivastava VK, Varjani S (2021) Valorization of dairy wastes: integrative approaches for value added products. Indian J Microbiol. https://doi.org/10.1007/s12088-021-00943-5

8. Lee JK, Patel SKS, Sung BH, Kalia VC (2020) Biomolecules from municipal and food industry wastes: an overview. Bioresour Technol 298:122346. https://doi.org/10.1016/j.biortech.2019. 122346

9. Kalia VC, Patel SKS, Shanmugam R, Lee JK (2021) Polyhydroxyalkanoates: trends and advances toward biotechnological applications. Bioresour Technol 326:124737. https://doi.org/10. 1016/j.biortech.2021.124737

10. Patel SKS, Gupta RK, Kalia VC, Lee JK (2021) Integrating anaerobic digestion of potato peels to methanol production by methanotrophs immobilized on banana leaves. Bioresour Technol 323:124550. https://doi.org/10.1016/j.biortech.2020.124550

11. Tan CH, Nomanbhay S, Shamsuddin AH et al (2021) Recent progress in harvest and recovery techniques of mammalian and algae cells for industries. Indian J Microbiol. https://doi.org/10. 1007/s12088-021-00930-w

Publisher's Note Springer Nature remains neutral with regard to jurisdictional claims in published maps and institutional affiliations. 